\title{
Through Eroticism to Sthitaprajnatwa: Paradoxes meet in I.B. Singer's Fiction
}

\author{
Dr V.V. Ushabala \\ Associate Professor \\ SMC College of Dairy Science, AAU, Anand
}

\begin{abstract}
When confronted with a choice between Sacred and Profane, Salvation and Satan, the human being seems quite justified in his vacillation between the flagitious temptation to give in to the ambient material pleasures, and the nagging fear of a Gehenna and a punishing God, of whose existence, he can never be certain. Hence, there exists in I.B. Singer's fiction a bizarre relation between sexuality and spirituality, between hedonistic impulses and piety. Singer himself affirms many a time that for him, it is merely one step away from sex to the study house. His own proclamations, blended with a revealing portrayal of his characters, if on one hand evokes the stark realities of Gogol, Dostoevsky, Isaac Babel, Peretz and Faulkner, on the other sets him apart from other Yiddish writers, and turn the Yiddish critics hostile towards him. In fact, many conservative Yiddish critics have condemned him for his shocking sexuality and have labeled him as a rebellious writer among the Yiddish elite. Corresponding to their notion, Singer's short fiction is mostly suffused with grotesque images of sex.
\end{abstract}

Keywords: eroticis, sthitaprajnatwa, sexuality, spirituality, I.B. Singer, fiction.

\section{Prologue}

"In the beginning was lust : All things exist in this Universe in pairs : Thus the upper clouds in the sky are male, the lower waters in the sea female; ...... all numbers, letters, prayers, commandments God's Holy names themselves form mysterious unions of male and female principle."

- Isaac Luria

When confronted with a choice between Sacred and Profane, Salvation and Satan, the human being seems quite justified in his vacillation between the flagitious temptation to give in to the ambient material pleasures, and the nagging fear of a Gehenna and a punishing God, of whose existence, he can never be certain. Hence, there exists in I.B. Singer's fiction a bizarre relation between sexuality and spirituality, between hedonistic impulses and piety. Singer himself affirms many a time that for him, it is merely one step away from sex to the study house. His own proclamations, blended with a revealing portrayal of his characters, if on one hand evokes the stark realities of Gogol, Dostoevsky, Isaac Babel, Peretz and Faulkner, on the other sets him apart from other Yiddish writers, and turn the Yiddish critics hostile towards him. In fact, many conservative Yiddish critics have condemned him for his shocking sexuality and have labeled him as a rebellious writer among the Yiddish elite. Corresponding to their notion, Singer's short fiction is mostly suffused with grotesque images of sex. Pious Jews with beards and ear locks, bowlegged matrons, aged and malformed - all are active participant in his lusty, erotic imagination. In brief, in most of Singer's short fiction, sex is employed as the Devil's ploy to incite man with thoughts of transgression, and hasten him to his perdition.

But in Singer's novels, Eros is assigned with a specific purpose, and is endowed with a philosophic hue, basically propagating the Holy Union. Singer, moreover, defends the sensuality in his fiction by saying, "I feel no shame of it. The Bible and the Talmud are full of sex stories. If these saints are not ashamed of it, why should I be, who am not a saint? If there is a God, I imagine Him as a Lover......" (Prescott 1978: 97). This cabalistic notion finds abundant expression in Singer's short story "The Sèance" "in Dr Kalisher's philosophy, for whom, “... all the suffering was nothing more than negative expressions of universal eroticism : Hitler, Stalin, the Nazis ... were actually searching for new forms and variations of sexual salvation." Dr Kalisher ultimately concludes that even Death is nothing but sexual amnesia! 


\section{ENUNCIATION}

It is the innuendo rather than the overt description that makes Singer's sensuality so overwhelming. Yasha Mazur, a $19^{\text {th }}$ century Polish magician from Lublin in Sinsger's The Magician of Lublin is a paragon of talent with little recognition and no riches. He has a Jewish wife Esther, a Gentile mistress Magda, a whore named Zeftel at Piask, and a noble Polish Christian sweetheart Emilia, who is a Professor's widow. While returning from the theatre in a droshky, a subtle description of the silent communication of desire from Yasha's body to Emilia's - "They both seemed to listen to the lust which moved from her knee to his and back again. Their bodies conversed in a wordless language of their own. 'I must have you', said one knee to the other....." is more connotative than the veritable love-act Yasha indulges in with Magda.

If Death is nothing but sexual amnesia for Singer, then Life too manifests a sort of sexual orgy. In his sexuality, Yasha Mazur attains a state where, he makes no discrimination between beauty and unsightliness; further, he treatsboth with the same intent or indifference. For instance, he caresses Magda's emaciated, rash-covered body with the same passion with which he kisses Emilia's alluring red lips. This disposition can be attributed either to the degenerate state in which only fervency and not beauty counts, or considering Yasha's occasional revelations, that acme of illumination as the one attained by a Hindu sage, where he revels only in God's creation irrespective of its attributes.

It may be pertinent here to recall the fervor of the Gopikas in the Mahabhagavata - the sacred Hindu religious text, a state known as the 'Sringara Yoga', where the explicit desire of the Gopikas for union with Lord Krishna is exegetical of a desire not for the release of base passion, but for a Union of the Jeevatma (Finite) with the Paramatma (Infinite). The Krishna Tatwa enunciates that the sage who isolates himself from material bonds in order to worship the Lord, would succeed at the most only in attaining proximity with the Lord, whereas, the actual physical commingling of the Gopikas with Shri Krishna reveals 'Rasa Siddhi', or the absolute amalgamation with the Paramatma.

\section{Conclusion}

The concept of 'Rasa Siddhi' finds symbolic expression in Singer's characters like Reb Gedaliya (Satan in Goray) and Jacob (The Slave), where he treats Torah, the prayer, the Commandments, and God's Holy Names themselves as the mysterious unions of the male and female principles. On a higher scale, Yasha's state may be treated as 'Samyak Drishti', 'SamyakBhavana', or to be more precise, 'Sthitaprajnatwa' where, life's dichotomy, paradoxes and diverse externalities cease to exist. It is a stage where the Sage concentrates only on the 'Atman' that resides even in the lowliest of God's creatures. To continue the analogy further, Lord Krishna preaches Arjunain the Bhagavad Gita:

Sarva bhutastha matmanam; sarva bhutani chatmani//

Eekshate yoga yuktatma; sarvatra sama darshanah//

(Chap.5, shloka 29)

(A man who is elevated to this spiritual sublimity attains such cosmic vision or samyak drishti, where he beholds God's glory alone in the highest or even in the lowest of beings; he perceives beauty or divinity in the entire creation, identifies the Finite with the Infinite, and evels in the omniscience of the Lord.)

If Singer's own views on Holy Union are taken into consideration, man experiences a kind of divine orgasm while even attempting to unite the Finite the Infinite. Singer's protagonists achieve spiritual salvation through sexual frustration, sexual indifference or, an absolute submission to their corporeal performance that amounts to the sublime union through meditation with the Supreme Soul. They inevitably experience coruscation or the Godly presence in the wildest throes of passion. In The Estate, for Ezriel, while uniting with his mistress Olga, everything becomes jumbled up - "Life and Death, Lublin and Wilna, Jewishness and apostasy, chastity and wantonness, tenderness and evil." It is a revelation complementing God's evil self, that evil is an inextricable part of the Divine system. For one who transcends earth's dichotomies, the apogee of physical pleasure involves a glimpse of the Divine Countenance.

Herman, the protagonist in Singer's Enemies, a Love Story, views his union with his mistress Masha as an integral part of the Divine Plan. He even attempts to analyze why the union of male and female was glorified in the Cabala. Masha evokes in him an animal energy, which is at once life giving and 
life destroying - a force like God Himself - creative and destructive. Basing on this, Herman fantasizes on inventing a new metaphysic, which would have its origin in the attraction of sexes: “... In the beginning was lust. The Godly as well as the human principle, is desire. Gravity, light, magnetism, thought may be aspects of the same universal longing. Suffering, emptiness, darkness are nothing more than interruptions of a cosmic orgasm that grows forever in intensity."

On a deeper analysis, Singer seems to attribute divinity to one human principle called lust, but practically to each and every organic and inorganic principles, which fact eventually establishes his protagonist as a mystic. As far as his characters' most human impulses are concerned, Singer never moralizes, nor displays any sort of librorum prohibitorum, ding which may condemn him to be merely a rabbi in the guise of a writer, most intangible to all human concerns. On the other hand, bestowing the physical union with a celestial hue certainly establishes him a self-proclaimed Priest of Eros.

\section{REFERENCES}

[1] Garrin, Stephen H. 1980. "Isaac Bashevis Singer in Texas: Public Speeches and a Private Interview". Texas Studies in Literature and Language. Spring:91-98.

[2] Bloom, Harold. 1975. Kabbalah and Criticism. New York: Seabury.

[3] Prescott, P.s. 1978. "Singer the Magician.” Newsweek 92(2):97-98.

[4] Ripp, A. 1982. "Nobel Prize Winner Isaac Bashevis Singer on Life, Sex and the Storyteller's Art." People's Weekly. 17:90.

[5] The Mahabhagavata (Narayaneeyam).

\section{AUTHOR's BIOGRAPHY}

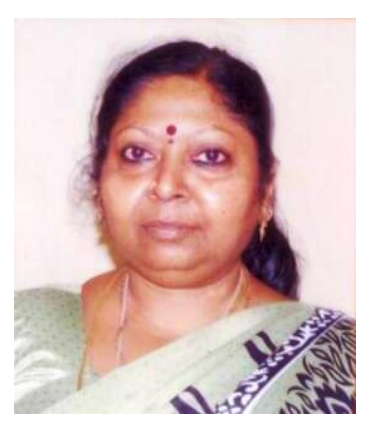

Dr V.V. Ushabala, is a recepient of Gold Medal and Best Thesis Award for the Doctoral Thesis in American Literature entitled "In Search of Faith: A Study of the Novels of Isaac Bashevis Singer". Presently working as Asso. Prof. at Anand Agricultural University (Gujarat - INDIA) 